\title{
Spring water deficit and soil conditions matter more than seed origin and summer drought for the establishment of temperate conifers
}

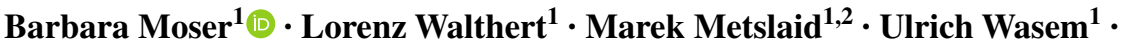 \\ Thomas Wohlgemuth ${ }^{1}$
}

Received: 4 February 2016 / Accepted: 3 November 2016 / Published online: 10 November 2016

(C) Springer-Verlag Berlin Heidelberg 2016

\begin{abstract}
In anticipation of more severe summer droughts, forestry in temperate Europe is searching for droughtresistant ecotypes of native tree species that might maintain ecosystem services in the future. We investigated how spring precipitation and soil conditions interact with summer drought and affect the establishment of conifer seedlings from different climatic origin. Emergence, establishment and subsequent performance of seedlings originating from autochthonous, Central Alpine, continental Eastern European, and Mediterranean Pinus sylvestris and Picea abies populations were studied in the dry Alpine Rhine valley, Switzerland, at three sites with differing soil water holding capacities and in 3 years with contrasting weather conditions. In addition to this natural inter-annual variation, precipitation was manipulated within sites with throughfall reduction roofs. Seedling establishment and growth were principally affected by the spring weather in the year of emergence. In years with average to positive spring water balance, seedlings grown at the site with the highest water holding capacity had 2-5 times more aboveground biomass than seedlings grown at sites with less favourable soils. Effects of seed origin were marginal and only detectable at
\end{abstract}

Communicated by Russell K. Monson.

Electronic supplementary material The online version of this article (doi:10.1007/s00442-016-3766-3) contains supplementary material, which is available to authorized users.

Barbara Moser

barbara.moser@wsl.ch

1 Swiss Federal Institute for Forest, Snow and Landscape Research WSL, Birmensdorf, Switzerland

2 Institute of Forestry and Rural Engineering, Estonian University of Life Sciences, Tartu, Estonia the drier sites: contrary to our expectations, seedlings from the Central Alpine Rhone valley, where the climatic spring water deficit is large, outperformed those from the Mediterranean. Consequently, plantation of non-native populations from dryer origin will mitigate the effects of increased summer drought at driest sites only, while the inter-annual variability of spring precipitation will continue to enable temperate conifers to regenerate on a wide range of forest soils independent of seed origin.

Keywords Climate change P Picea abies.

Pinus sylvestris $\cdot$ Soil moisture $\cdot$ Tree seedlings

\section{Introduction}

Rising temperatures and increasing frequency and duration of dry spells are expected to result in a northward shift of suitable climate for European tree species (Thuiller et al. 2006; Hanewinkel et al. 2013; Lindner et al. 2014). It has been questioned, however, whether long-lived woody species will be able to keep track with rapidly changing climate and reach the sites with favourable growing conditions before they become extinct at lower latitudes (Lischke et al. 2006; Aitken et al. 2008; Renwick and Rocca 2015). Together with recurrent accounts of drought-induced tree mortality (Bigler et al. 2006; Carnicer et al. 2011; Hereş et al. 2014), this has triggered a debate about the future management of temperate European forests. Plantation of ecotypes from the dry end of current species ranges or the introduction of more drought tolerant non-native tree species has been proposed to maintain forest productivity and other ecosystem services (Kapeller et al. 2012; Hanewinkel et al. 2013; Bussotti et al. 2015). But, an extensive transplant study in the South-Eastern United States revealed that 
seedlings of potential migrant species from warmer regions did not perform better than native tree species under drier conditions (Ibàñez et al. 2009). Ecotypic differences between populations might be offset by environmental heterogeneity, which has been widely neglected in climate manipulation experiments and modelling studies. Buffering of climate change effects seems to occur in terms of soil heterogeneity (Fridley et al. 2011; Fridley and Wright 2012; García-Palacios et al. 2012; Piper et al. 2013), finescale thermal variability, which exceeds the expected climate warming in both topographically complex and flat terrain (Scherrer and Körner 2011; Lenoir et al. 2013; Slavich et al. 2014), as well as with respect to the tempering effects of forest canopy (von Arx et al. 2013). This is in line with Leuzinger et al. (2011), who demonstrated that effect sizes of climate change impacts diminish rapidly once models and experiments incorporate more than two factors or target a regional rather than a local scale.

Uncertainties in the projection of future tree ranges further relate to the fact that projections of precipitation changes, potentially the main driver of future tree regeneration on xeric sites in Central Europe (Richter et al. 2012), are highly uncertain with respect to magnitude as well as spatial and temporal extent (Hawkins and Sutton 2011; Fischer et al. 2015). Drought does not affect trees uniformly over the year and effects depend on site water balance. Lévesque et al. (2014) showed, for instance, that tree-ring width of Pinus sylvestris and Picea abies is negatively affected by summer drought on mesic sites, while water deficit from previous autumn to spring seems to be decisive on xeric sites. The latter corresponds well with the timing of xylem and phloem formation of the two species at lower elevations, which peaks between April and May (Swidrak et al. 2014). Not only tree growth but also tree regeneration is tied to the spring season, when seed germination takes place. Especially in smaller seeded species with limited nutrient storage such as $P$. sylvestris and $P$. abies, to be or not to be may be decided before the beginning of the summer season (Castro 2006). Given the different timing of the rainy season between the Mediterranean (winter/spring) and Central Europe (summer), Mediterranean tree species or Mediterranean ecotypes of temperate tree species may not necessarily be better adapted to the future climatic conditions projected for Central Europe, as has been suggested based on experiments studying summer drought (Richter et al. 2012; Taeger et al. 2013; Thiel et al. 2014).

We tested whether ecotypes of $P$. sylvestris and P. abies from the dry end of both species' distribution ranges establish more successfully than autochthonous populations under the future climatic conditions of the dry Alpine Rhine valley, Switzerland. Germination and early seedling establishment of autochthonous and non-autochthonous populations from the Central Alpine Rhone valley (no distinct rainy season), continental Eastern Europe (rainy season in summer), and the Mediterranean (rainy season in the winter half-year) were studied in small clear-cuts with different soil water holding capacities and in 3 years with contrasting weather conditions. Throughfall reduction roofs were used to simulate a potential decrease in water availability during the growing season, as projected for the studied region by the end of the twenty-first century (Fischer et al. 2015).

\section{Materials and methods}

\section{Species and seed material}

Pinus sylvestris L. and Picea abies (L.) H. Karst. are the most widespread conifers in Europe, ranging from southern Spain (P. sylvestris) and the Balkan peninsula to Scandinavia and Siberia (Mátyás et al. 2003; Skrøppa 2003; Fig. 1). In Central Alpine valleys, $P$. sylvestris dominates lowelevation forests between 600 and $1300 \mathrm{~m}$ a.s.l, whereas $P$. abies prevails at higher elevation. In Central Europe, $P$. abies has been extensively planted outside its natural range to maximise wood production, especially at low elevations, where its longer-term persistence is questioned in the advent of climatic change (Hanewinkel et al. 2010). We collected seeds of both species from autochthonous populations on dry sites in the Rhine valley (autochthonous seed source), the Rhone valley (Central Alps), Tyrol, the Vienna basin, Transylvania (continental Eastern Europe), and, in the case of $P$. sylvestris, across the Mediterranean (Table 1; Fig. 1). Seeds from 3-5 trees per population were mixed in equal parts before sowing.

\section{Sites and experimental setup}

The experiment was set up in the Rhine valley near Chur, Switzerland, and included three forest sites located on south-facing, low-elevation slopes (750-850 $\mathrm{m}$ a.s.1.) with calcareous parent material (Table 2). The soils were classified as brown earth or rendzina, all with medium to moderately fine textured surface horizons (clay content between 20 and $25 \%$ ) and a low to medium fine-earth bulk density of $0.65-1.26 \mathrm{~g} \mathrm{~cm}^{-3}$ (methods followed Walthert et al. 2004; detailed description in Moser et al. 2015). Although the soils have similar textures and fine-earth bulk densities, their water holding capacity differs considerably. While site 2 is located on compact rockslide material hardly penetrable to roots (piercing with a soil corer of $1 \mathrm{~cm}$ diameter revealed an average soil depth of $39 \mathrm{~cm} \pm 15 \mathrm{~cm} \mathrm{SD}$; $N=40$ ), the soil at site 3 is gravelly with a coarse fragment fraction of $30 \%$ in the surface horizon and $>70 \%$ in the parent material horizon. Consequently, the plant available water holding capacity (AWC), calculated according 


\section{(a)Pinus sylvestris}
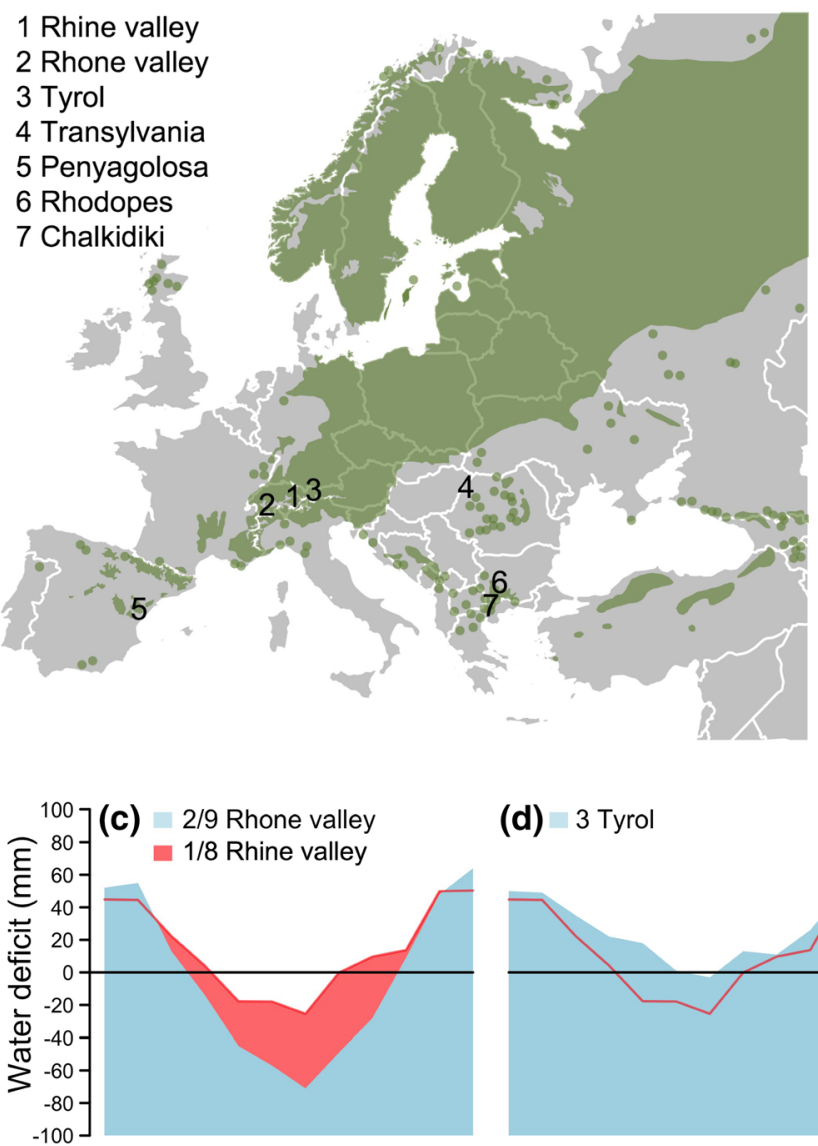

(d) 3 Tyrol
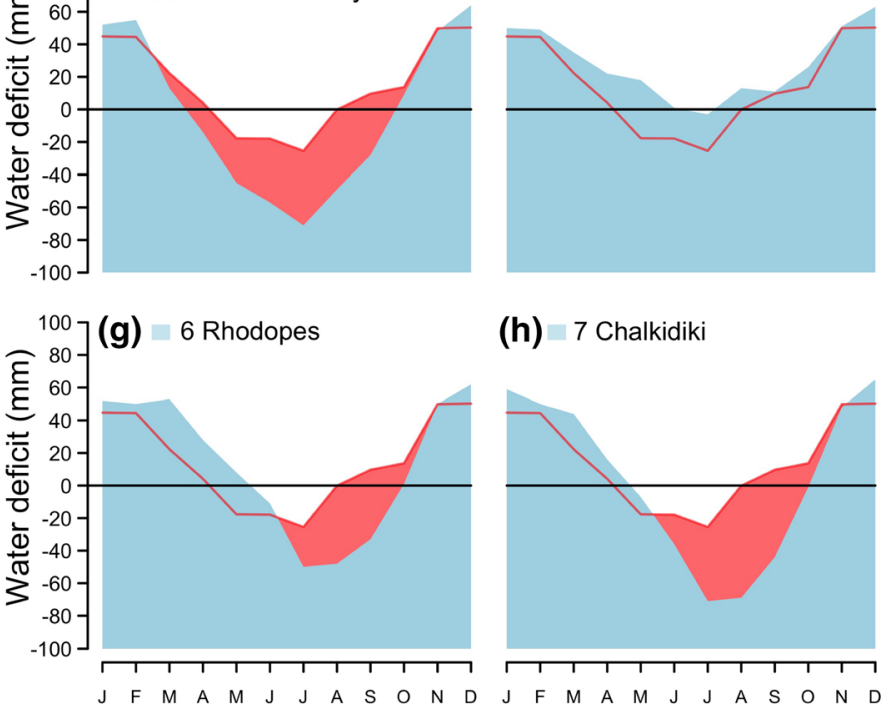

(h) 7 Chalkidiki

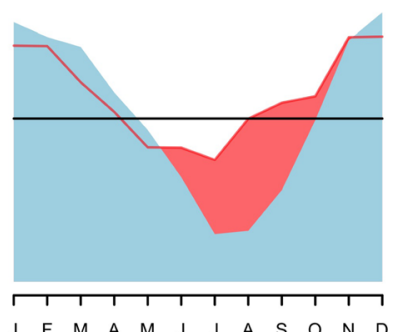

(b) Picea abies
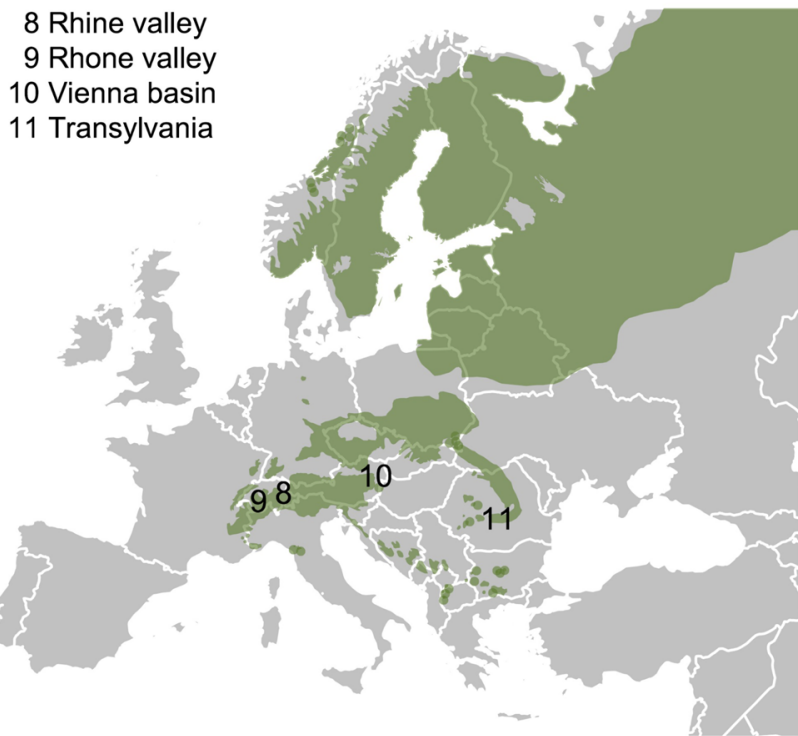

(e) 4 Transylvania

(f) $\square 5$ Penyagolosa
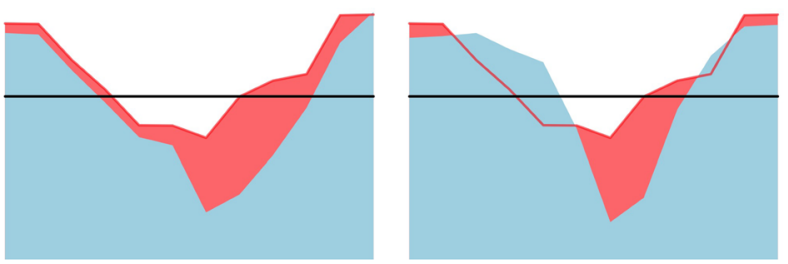

(i) 10 Vienna basin

(j) 11 Transylvania
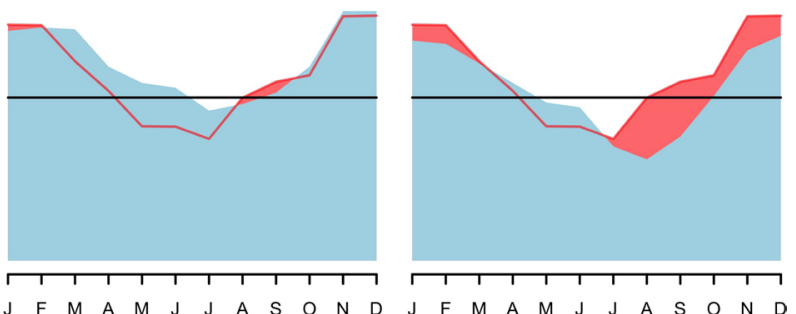

Fig. 1 Distribution of a Pinus sylvestris and b Picea abies in Europe (http://www.euforgen.org) and origin of the seeds used in the experiment (cf. Table 1). $\mathbf{c}-\mathbf{j}$ Comparison of monthly climatic water deficit $(\mathrm{mm})$ at the seed origin (blue) and the location of the autochthonous population in the Rhine valley (orange). Meteorological data refer to the period 1950-2000 and were provided by MeteoSwiss $(1,2,8,9)$ and http://www.worldclim.org $(3-7,10,11)$, respectively. A colour version of the figure is available in the online journal to Teepe et al. (2003), was highest at site 1 and lowest at site 3 (Table 2).

The sites underwent clear cutting in an area of 0.1 ha in winter 2009/2010 to guarantee equal light conditions for all experimental units. In spring 2010, 10 sowing plots of $50 \mathrm{~cm} \times 50 \mathrm{~cm}$ were prepared at each site by removing the vegetation and sieving the top $10 \mathrm{~cm}$ of the soil to $5 \mathrm{~mm}$ to create a uniform seedbed. At each sowing plot, a precipitation throughfall reduction roof of $1.5 \mathrm{~m} \times 1.5 \mathrm{~m}$ was installed, which consisted of $16 \mathrm{~V}$-shaped plastic channels (Online Resource 1). The channels were mounted so that, in theory, either 100 or $33 \%$ of the precipitation should reach the soil surface. Throughfall measurements revealed that in reality $40 \%( \pm 18 \%)$ of the actual precipitation 
Table 1 Seed origin, climatic conditions at the seed origin $\left(T_{\mathrm{Jan}}\right.$ average January temperature, $T_{\mathrm{Jul}}$ average July temperature, $P$ average annual precipitation, $W D_{A M J}$ water deficit Apr-Jun, $W D_{J A S}$ water deficit Jul-Sep), and seed quality in terms of germination rate (\%) under laboratory conditions (200 seeds incubated on filter paper at $25 / 13{ }^{\circ} \mathrm{C}$ day/night cycles and $90 \%$ humidity) of Pinus sylvestris and Picea abies populations included in the experiment

\begin{tabular}{|c|c|c|c|c|c|c|c|c|c|c|}
\hline \multirow[t]{2}{*}{ ID } & \multirow[t]{2}{*}{ Origin } & \multirow{2}{*}{$\begin{array}{l}\text { Elevation } \\
\text { (m a.s.l.) }\end{array}$} & \multirow[t]{2}{*}{$T_{\mathrm{Jan}}\left({ }^{\circ} \mathrm{C}\right)$} & \multirow[t]{2}{*}{$T_{\mathrm{Jul}}\left({ }^{\circ} \mathrm{C}\right)$} & \multirow[t]{2}{*}{$P(\mathrm{~mm})$} & \multirow[t]{2}{*}{$\mathrm{WD}_{\mathrm{AMJ}}(\mathrm{mm})$} & \multirow[t]{2}{*}{$\mathrm{WD}_{\mathrm{JAS}}(\mathrm{mm})$} & \multicolumn{3}{|c|}{ Germination lab } \\
\hline & & & & & & & & 2010 & 2011 & 2013 \\
\hline \multicolumn{11}{|c|}{ Pinus sylvestris } \\
\hline 1 & Rhine valley, Switzerland & 570 & 0.0 & 17.9 & 810 & -24 & -8 & 97 & 96 & 94 \\
\hline 2 & Rhone valley, Switzerland & 560 & -0.7 & 19.2 & 603 & -116 & -148 & 96 & 98 & 97 \\
\hline 3 & Tyrol, Austria & 710 & -1.7 & 17.2 & 917 & 41 & 20 & 95 & 92 & 86 \\
\hline 4 & Transylvania, Romania & 120 & -2.0 & 20.7 & 609 & -59 & -167 & - & - & 42 \\
\hline 5 & Penyagolosa, Spain & 1200 & 1.2 & 17.8 & 687 & 30 & -147 & - & - & 100 \\
\hline 6 & Rhodopes, Bulgaria & 1400 & -3.8 & 15.1 & 664 & 25 & -131 & - & - & 93 \\
\hline 7 & Chalkidiki, Greece & 1360 & -1.8 & 17.4 & 613 & -27 & -183 & - & - & 86 \\
\hline \multicolumn{11}{|c|}{ Picea abies } \\
\hline 8 & Rhine valley, Switzerland & 670 & 0.0 & 17.9 & 810 & -24 & -8 & 49 & 53 & 79 \\
\hline 9 & Rhone valley, Switzerland & 620 & -0.7 & 19.2 & 603 & -116 & -148 & 78 & 53 & 45 \\
\hline 10 & Vienna basin, Austria & 800 & -3.7 & 16.3 & 835 & 35 & -8 & 61 & 62 & 63 \\
\hline 11 & Transylvania, Romania & 600 & -4.0 & 18.5 & 669 & 0 & -91 & - & - & 75 \\
\hline
\end{tabular}

Meteorological data refer to the period 1950-2000 and were provided by MeteoSwiss (1, 2, 8, 9) and http://www.worldclim.org (3-7, 10, 11)

Table 2 Location and soil characteristics of the experimental sites. Plant available water holding capacity (AWC) was calculated according to Teepe et al. (2003) and refer to $0-100 \mathrm{~cm}$ soil depth (site 2: $0-39 \mathrm{~cm}$, according to the soil depth measurements)

\begin{tabular}{|c|c|c|c|}
\hline & Site 1 & Site 2 & Site 3 \\
\hline Latitude/longitude & $46.84 / 9.44$ & $46.82 / 9.37$ & $46.84 / 9.43$ \\
\hline Elevation (m a.s.l.) & 720 & 730 & 820 \\
\hline Soil type & Brown earth & Rendzina & Rendzina \\
\hline $\mathrm{AWC}(\mathrm{mm})$ & 145 & 117 & 75 \\
\hline Ammonium $\left(\mathrm{mg} \mathrm{l}^{-1}\right)$ & $0.44 \pm 0.03$ & $0.34 \pm 0.04$ & $0.59 \pm 0.08$ \\
\hline Nitrate $\left(\mathrm{mg} \mathrm{l}^{-1}\right)$ & $82.1 \pm 11.4$ & $110.2 \pm 29.3$ & $41.7 \pm 8.1$ \\
\hline Phosphate $\left(\mathrm{mg} \mathrm{l}^{-1}\right)$ & $<0.15$ & $<0.15$ & $<0.15$ \\
\hline
\end{tabular}

reached the soil surface under the 100\%-roofs, and $26 \%$ $( \pm 18 \%)$ under $33 \%$-roofs. We assume that the unexpected throughfall reduction under the $100 \%$-roofs was due to a considerable amount of water drops sticking to the channels and evaporating before falling on the ground (interception effect). The roofs were in place from April to October each year.

The sowing plots were divided into 25 quadrats of $10 \mathrm{~cm} \times 10 \mathrm{~cm}$ and each quadrat was sown with $15-20$ seeds of one random combination of species and population in April 2010, 2011, and 2013, respectively. Some combinations of species and population were sown in 1 year only (Table 1). The sowing plots were covered by a wire cage during the first five months after sowing to prevent seed predation and herbivory from mice and birds.

\section{Environmental measurements}

Soil moisture in the topsoil was measured with matric potential sensors (MPS-1; Decagon, Pullman, USA). In 2010 , measurements in four sowing plots at $15 \mathrm{~cm}$ soil depth showed that soil moisture varied more between sowing plots than between roof types and experimental sites. As a consequence, we continuously added sensors so that by 2014, 30 MPS-1 sensors had been installed at $15 \mathrm{~cm}$ soil depth and 12 sensors at $5 \mathrm{~cm}$ soil depth. Precipitation (ARG100 tipping bucket raingauge, Campbell Scientific, Loughborough, UK), temperature and relative humidity (EL-USB-2+ sensors, Lascar Electronics, Salisbury, UK) were measured $2 \mathrm{~m}$ above ground from 2010 to 2014. Several of these sensors were temporarily damaged, so that we used continuous meteorological data from a nearby meteorological station (Chur, MeteoSwiss) for data analyses. Locally measured data did not differ between sites nor from the data measured at the MeteoSwiss station (ANOVA of monthly averages April 2010 -September 2014: temperature $F_{3,99}=0.349, P=0.790$; precipitation $F_{3,80}=1.318$, $P=0.274)$. Based on these data, quarterly water deficits (precipitation - potential evapotranspiration; Thornthwaite 1948) were calculated as a measure of seasonal weather conditions (spring: April-June; summer: July-September; growing season: April-September).

Nutrient availability was estimated with ion-exchange resin bags, one of which was buried at the border of each sowing plot at $5 \mathrm{~cm}$ soil depth between April and November 2014. Methods followed Schleppi et al. (2012) except 
that we extracted ions by shaking the resin of each bag in $80 \mathrm{ml} 1 \mathrm{M} \mathrm{KCl}$ for $1.5 \mathrm{~h}$. Ammonium was measured with flow injection analysis; nitrate and phosphate were analysed with ion chromatography after removing chloride from the solution (laboratory of the Swiss Federal Research Institute WSL, accredited according to ISO17025). Phosphate concentrations did not reach the limit of detection of $0.15 \mathrm{mg} \mathrm{l}^{-1}$.

\section{Seedling measurements}

Seedling emergence and mortality were initially recorded bi-weekly, later monthly. Aboveground biomass (dry weight) of a random sample of 1-18 seedlings per sowing quadrat was measured at the end of the second growing season. In 2014, differences in photosynthetic activity between study sites and populations were investigated using thermal imaging (Costa et al. 2013). On a daily scale, crown temperatures of stressed and non-stressed trees are most distinctive when photosynthetic activity is reduced due to stress (Bachofen et al., unpublished data). Differences increase with the duration of the drought (Scherrer et al. 2011). In a first step, we thus analysed the diurnal pattern of assimilation by measuring stomatal conductance with leaf porometers (SC-1; Decagon, Pullman, USA) on a small number of seedlings at $1.5 \mathrm{~h}$ intervals between dawn and dusk. We found an assimilation peak between 9 a.m. and 1 p.m. followed by a gradual decline until dusk (Online Resource 2). Based on these data, we chose late afternoon to estimate stomatal conductance of all seedlings by thermal imaging: at each site, four thermal images were taken per plot (VarioCAM hr, InfraTec GmbH, Dresden, Germany) between 3 p.m. and 6 p.m. on a cloudless day in August 2014. Each plot contained a wet reference surface (Reinert et al. 2012) to calculate relative crown temperature $\Delta T_{\text {Wet-Crown }}$, where $T_{\text {Crown }}$ is the minimum crown temperature of one quadrat and $T_{\text {Wet }}$ the surface temperature of the wet reference, both determined with the IRBIS 3 software (InfraTec $\mathrm{GmbH}$, Dresden, Germany; Online Resource 2). Using relative instead of absolute crown temperature allowed us to compare plots and sites even if environmental conditions differed (Scherrer et al. 2011).

\section{Data analyses}

The rate of emergence and the number of seedlings present at the end of the first growing season were standardised based on the number of sown seeds and germination rates under laboratory conditions (seed quality), i.e., emergence and number of seedlings refer to 100 viable seeds. Standardisation was necessary because seed quality varied considerably between species and populations (Table 1). Effects of site, roof type, seed origin and weather on seedling emergence and aboveground biomass were analysed with linear mixed models (LME; R package lmerTest; $\mathrm{R}$ Core Team 2015). For analyses of the effect of weather on seedling establishment and seedling growth, only those populations that were sown in all 3 years were included. Effects of seed origin were studied in more detail in the 2013 cohort, which contained a larger number of populations than other cohorts and measurements also included crown temperature. Poor seed quality considerably reduced emergence of the $P$. sylvestris population from Transylvania so that this population had to be excluded from the analysis of seedling establishment. Differences in plant available water and nutrients between sites, roof types, and soil depth were analysed with analysis of variance (ANOVA).

\section{Results}

\section{Water and nutrient availability}

Weather and roof type affected soil moisture differently at the three study sites. At the site with the highest water holding capacity, average matric potential from April to September and the number of dry days (matric potential $<-100 \mathrm{kPa}$ ) at $15 \mathrm{~cm}$ soil depth were related neither to climatic water deficit during the growing season nor to roof type (site 1; Online Resource 3). At the other sites, however, the matric potential was lower and dry days more numerous under the $33 \%$-roofs than under the $100 \%$-roofs. Only at the driest site (site 3), the number of dry days was negatively related to the climatic water deficit of the growing season (Online Resource 3). The average matric potential and the number of dry days from April to September 2014 did not differ between $5 \mathrm{~cm}$ and $15 \mathrm{~cm}$ soil depth (ANOVA on 24 sensors: $F_{1,12}=0.016, P=0.900$; $\left.F_{1,12}=0.046, P=0.834\right)$.

Plant available nutrients measured in terms of ammonium and nitrate differed neither between study sites nor between roof types (ANOVA, $P>0.05$; Table 2).

\section{Weather and site effects on seedling performance}

Seedling establishment involves a series of events such as seed germination, seedling emergence and survival, which result in differing seedling numbers. The number of $P$. sylvestris seedlings that had established by the end of the first growing season was first and foremost affected by climatic spring water deficit (Table 3 ). In years with favourable spring weather conditions, three to five times more seedlings emerged and survived than in years with a dry spring season (Fig. 2a). Establishment also depended on study site (Table 3 ), with a 1.5 to 3 -fold higher number of seedlings at site 1 (high AWC) than site 3 (poor AWC). 
Table 3 Results of linear mixed effects models for the effects of study site, roof type, seed origin as well as spring (Apr-Jun) and summer (Jul-Sep) water deficit in the in the year of seedling emergence $\left(\Delta \mathrm{WD}_{\mathrm{AMJ}}\right.$ site 1 st year and $\Delta \mathrm{WD}_{\mathrm{JAS}}$ site 1 st year, respec- tively) and in the second growing season ( $\triangle \mathrm{WD}_{\mathrm{AMJ}}$ site 2 nd year and $\Delta \mathrm{WD}_{\mathrm{JAS}}$ site 2nd year, respectively) on the standardised number of seedlings at the end of the first growing season and aboveground biomass at the end of the second growing season (details s. Fig. 2)

\begin{tabular}{|c|c|c|c|c|c|c|c|c|c|c|c|c|}
\hline \multirow[t]{3}{*}{ Source of variation } & \multicolumn{6}{|c|}{ Pinus sylvestris } & \multicolumn{6}{|c|}{ Picea abies } \\
\hline & \multicolumn{3}{|c|}{ No of seedlings } & \multicolumn{3}{|c|}{ Biomass $(\mathrm{g})^{\mathrm{a}}$} & \multicolumn{3}{|c|}{ No of seedlings } & \multicolumn{3}{|c|}{ Biomass $(\mathrm{g})^{\mathrm{a}, \mathrm{b}}$} \\
\hline & $d f$ & $F$ & $P$ & $d f$ & $F$ & $P$ & $d f$ & $F$ & $P$ & $d f$ & $F$ & $P$ \\
\hline Study site & 2,26 & 13.8 & $<0.001$ & 2,24 & 13.6 & $<0.001$ & 2,26 & 22.9 & $<0.001$ & - & - & - \\
\hline Roof type & 1,26 & 0.3 & 0.572 & 1,23 & 2.6 & 0.123 & 1,26 & 7.6 & 0.010 & 1,48 & 2.8 & 0.100 \\
\hline Seed origin & 2,236 & 1.5 & 0.229 & 2,150 & 2.7 & 0.072 & 2,236 & 4.7 & 0.010 & 2,48 & 0.8 & 0.435 \\
\hline$\Delta \mathrm{WD}_{\mathrm{AMJ}} 1$ st year & 1,236 & 136.6 & $<0.001$ & 1,154 & 55.3 & $<0.001$ & 1,236 & 16.5 & $<0.001$ & 1,48 & 47.7 & $<0.001$ \\
\hline$\Delta \mathrm{WD}_{\mathrm{JAS}} 1$ st year & 1,236 & 7.4 & 0.007 & 1,157 & 1.5 & 0.226 & 1,236 & 0.3 & 0.561 & 1,48 & 0.0 & 0.954 \\
\hline$\Delta \mathrm{WD}_{\mathrm{AMJ}} 2$ nd year & - & - & - & 1,162 & 0.0 & 0.917 & - & - & - & 1,48 & 0.1 & 0.788 \\
\hline$\Delta \mathrm{WD}_{\mathrm{JAS}} 2$ nd year & - & - & - & 1,164 & 0.2 & 0.631 & - & - & - & 1,48 & 1.4 & 0.246 \\
\hline
\end{tabular}

Bold indicate $P$ values $<0.05$

${ }^{a}$ Log-transformed

${ }^{\mathrm{b}}$ Only site 1 included in the model because low seedling emergence made the experimental design unbalanced at the other sites

A small climatic water deficit during summer increased survival but its effect on seedling establishment was considerably smaller than that of climatic spring water deficit and site characteristics, as indicated by the substantially lower $F$ value (Table 3 ). At site 1 , more than 20 out of 100 viable seeds successfully established in all years, while at the other sites this number was reached only in years with average to wet spring conditions. The aboveground biomass of 2-year-old seedlings was still affected by the climatic spring water deficit in the year of germination but not by later weather conditions, i.e., neither summer water deficit in the year of germination, nor spring or summer water deficit during the second growing season (Table 3). Site effects were also pronounced, though less important than spring weather (fourfold smaller $F$ value, Table 3 ), and differences between sites mirrored those found with respect to seedling establishment (Fig. 2b). We found no differences in seedling numbers or aboveground biomass between roof types and populations (Rhine valley, Rhone valley, Tyrol).

In $P$. abies, seedling establishment followed similar patterns as in $P$. sylvestris only that site and spring weather effects were of similar magnitude (Table 3). Although establishment success varied between populations (Rhine valley, Rhone valley, Vienna basin), we found no consistent differences between populations with respect to sites and/or spring weather conditions (Fig. 2a). Seedling numbers were almost twice as high under the $100 \%$ roofs $(30 \pm 4$ SE) than under the $33 \%$ roofs $(16 \pm 3$; Table 3$)$ despite the fact that soil moisture did not differ between the two roof types (Online Resource 3). Overall, P. abies only reached sizeable numbers of seedlings at the site with the highest AWC (site 1, Fig. 2b). Consequently, the experimental design was unbalanced and analyses of second year biomass were possible at site 1 only. Consistent with $P$. sylvestris, the aboveground biomass depended on the spring water deficit in the year of germination but not on later weather conditions (Table 3). Although not statistically verified, differences in seedling biomass between study sites resembled those of establishment success (Fig. 2).

\section{Populations from drier climates}

The performance of autochthonous populations compared to those from the Central Alps, Eastern Europe or the Mediterranean was studied in more detail in the 2013 cohort, which included seven $P$. sylvestris and four $P$. abies populations (Table 1). The number and aboveground biomass of $P$. sylvestris seedlings were again mainly driven by site characteristics (LME, $F_{2,27}=17.0, P<0.001$; $\left.F_{2,22}=33.5, P<0.001\right)$ and differences between populations were small (LME, $F_{5,135}=2.7, P=0.022$; $\left.F_{6,101}=2.8, P=0.015\right)$. Neither establishment nor biomass was related to climatic parameters that potentially indicate local adaptation to summer drought, such as mean July temperature and precipitation or climatic water deficit during summer (Online Resource 4). But, biomass of seedlings growing under reduced precipitation (33\%-roof type) at sites 2 and 3 was marginally higher in populations from locations with a negative climatic spring water balance than those from locations with a positive balance (Fig. 3a). 

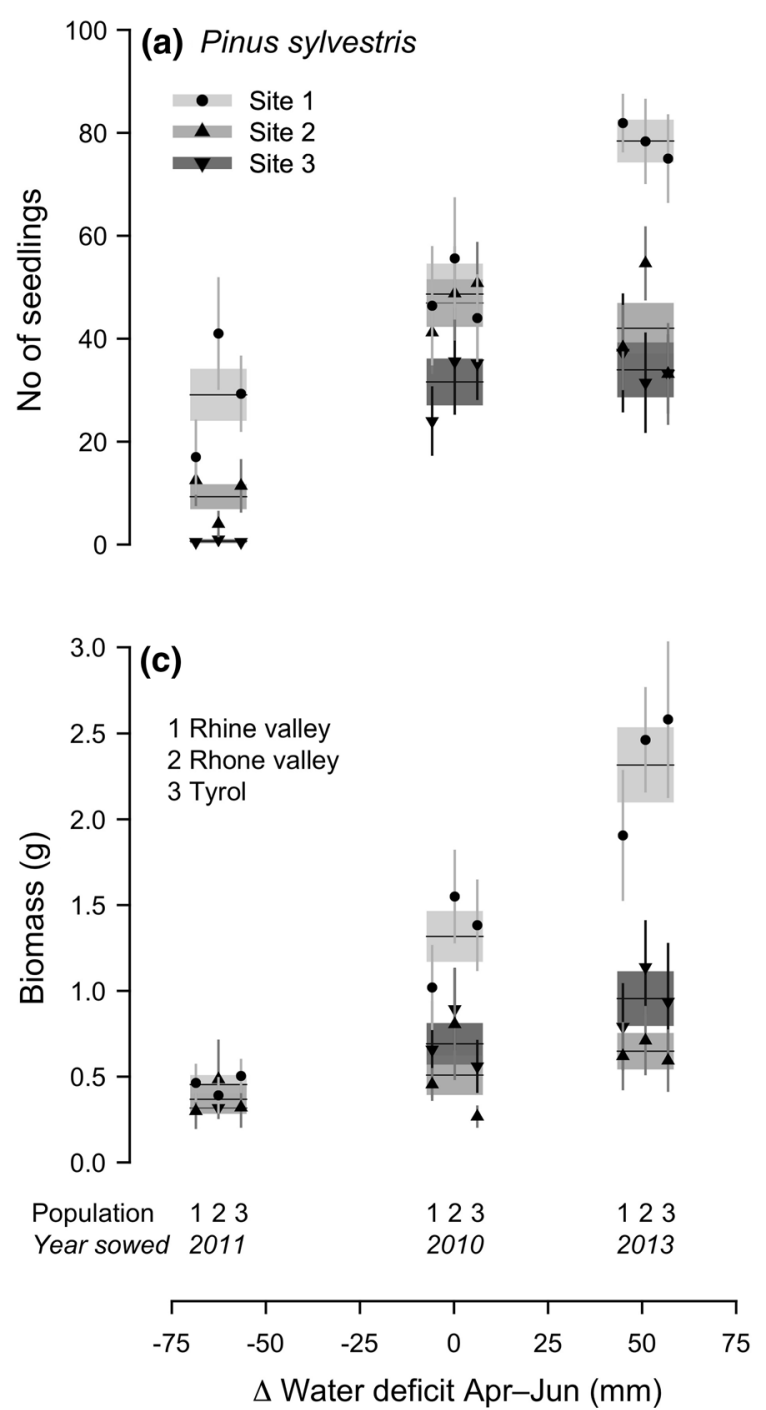

Fig. 2 Establishment and growth of Pinus sylvestris and Picea abies seedlings in relation to weather at the time of emergence, site and seed origin: a, b standardised number of seedlings at the end of the first growing season; $\mathbf{c}, \mathbf{d}$ aboveground biomass at the end of the second growing season (symbols/vertical bars population means $\pm \mathrm{SE}$;

At site 3, this corresponded to estimates of stomatal conductance that show marginally higher transpiration and concomitant lower crown temperature in seedlings from locations with a negative climatic spring water balance (Fig. 3b).

Due to the limited number of $P$. abies populations in the 2013 cohort, correlations with climatic parameters at the seed origin are rather arbitrary. Nevertheless, we found a higher number of established seedlings in the Rhone valley population, the seed origin with the most negative climatic water balance in spring, than in the population from the Vienna basin with a positive April-Jun water balance (LME, $F_{3,32}=2.9, P=0.049$; Fig. 4).

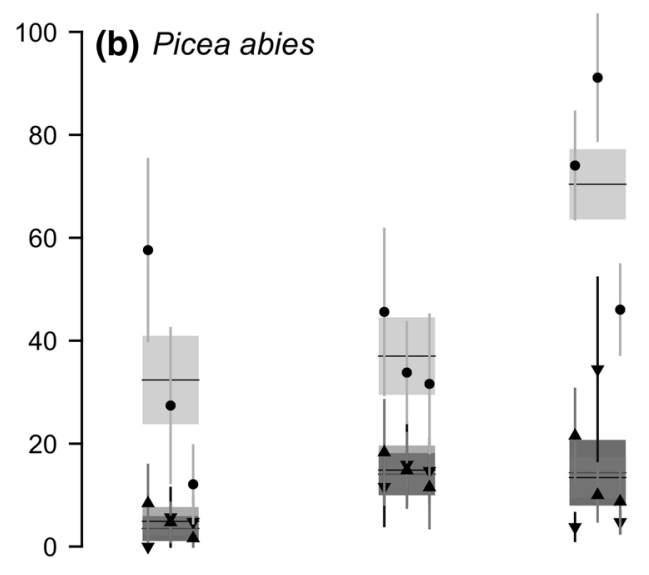

(d)

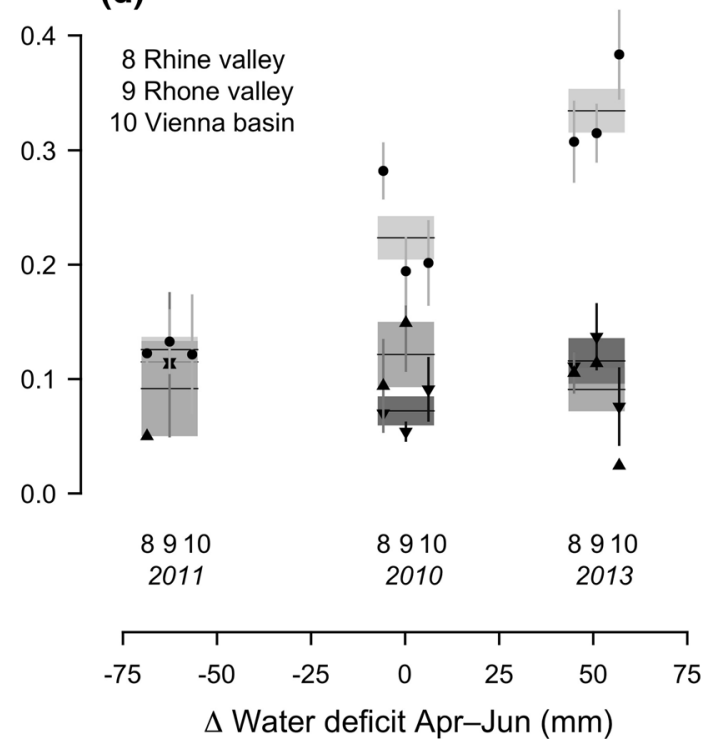

horizontal bars/polygons site means $\pm \mathrm{SE}$ ). Weather during the three months following seed sowing ( $\Delta$ water deficit Apr-Jun) was defined as the deviation of the water deficit from the long-term average in the Rhine valley $(-39 \pm 61 \mathrm{~mm} \mathrm{SD})$. Only populations that were sown in all years are shown

\section{Discussion}

\section{Seasonal water availability and soil heterogeneity}

Studying seedling establishment in several years with contrasting weather conditions demonstrated a huge impact of spring weather not only on seedling emergence but also on longer-term seedling performance. Climatic water balance during very early establishment outweighed effects of later weather conditions and seed origin (Table 3), which is not surprising since germination requires moist conditions and emerging seedlings are prone to desiccation until they have established an adequate root system (Castro 2006; 

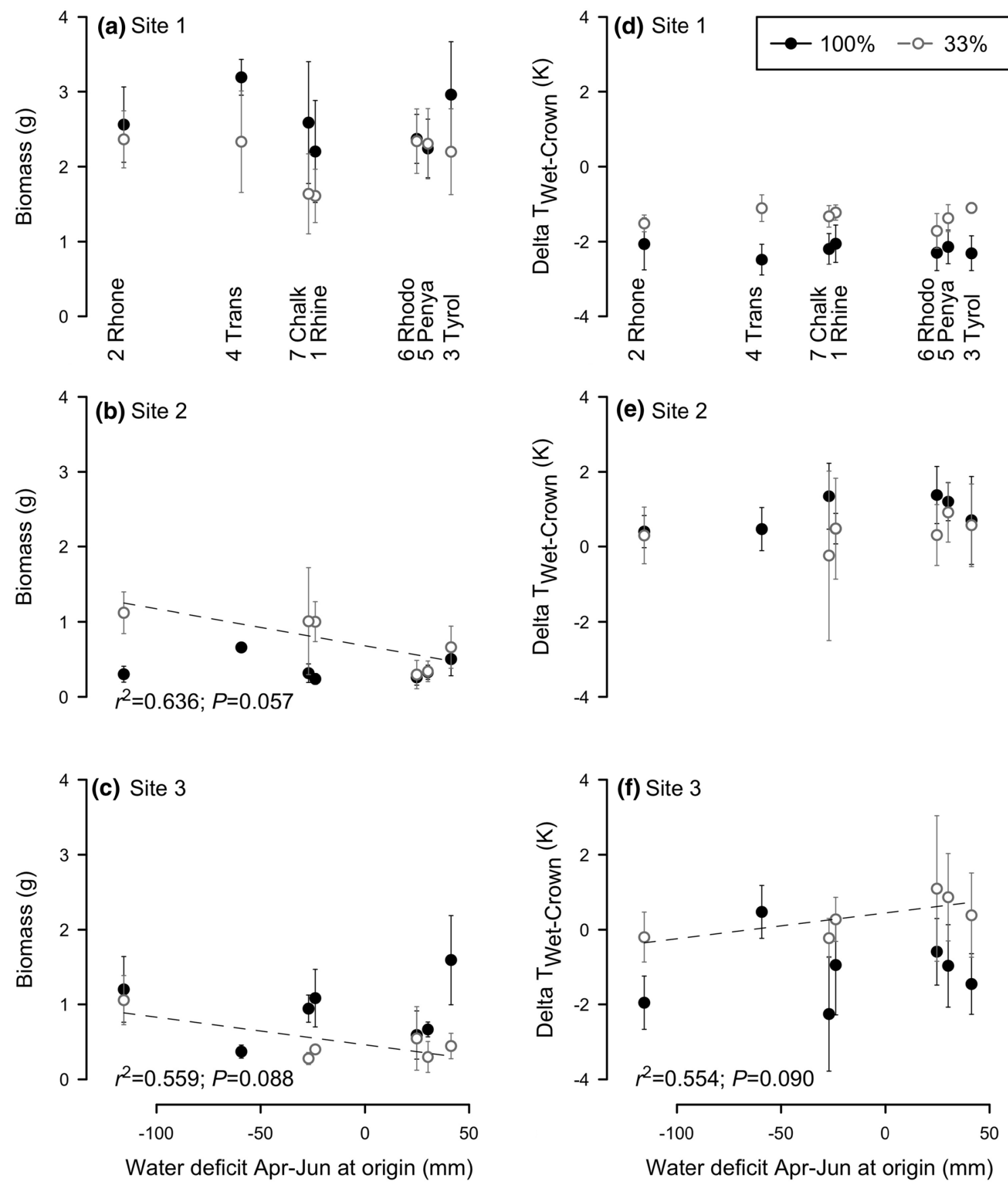

Fig. 3 Performance of 2-year-old Pinus sylvestris seedlings sowed in 2013 depending on study site, roof type and average spring water deficit at the seed origin (s. Table 1): a-c aboveground biomass (mean $\pm \mathrm{SE}$ ); $\mathbf{d}-\mathbf{f}$ leaf conductance measured as the thermal differ-

Dobrowski et al. 2015). Environmental conditions during emergence and early establishment did not only define the number of seedlings that emerged and survived in a particular year but also affected their size (Fig. 2). The observed drought-induced reduction of seedling size was still noticeable 2 years after emergence, potentially hampering the seedlings' ability to compete with surrounding vegetation.

ence between the minimum crown temperature $\left(T_{\text {Crown }}\right)$ and a wet artificial reference surface $\left(T_{\text {Wet }} ;\right.$ mean $\left.\pm \mathrm{SE}\right)$. The lower $\Delta T_{\text {Wet-Crown }}$, the higher the leaf conductance of a seedling

The number of seedlings that were able to establish in the driest year was so low and their size up to 2 years after emergence was so small that they are unlikely to contribute to long-term forest regeneration. This is in accordance with the facts that tree regeneration occurs in pulses (Grubb 1977; Zackrisson et al. 1995; Savage et al. 1996) and juveniles occupy a moister niche than adults in water limited 

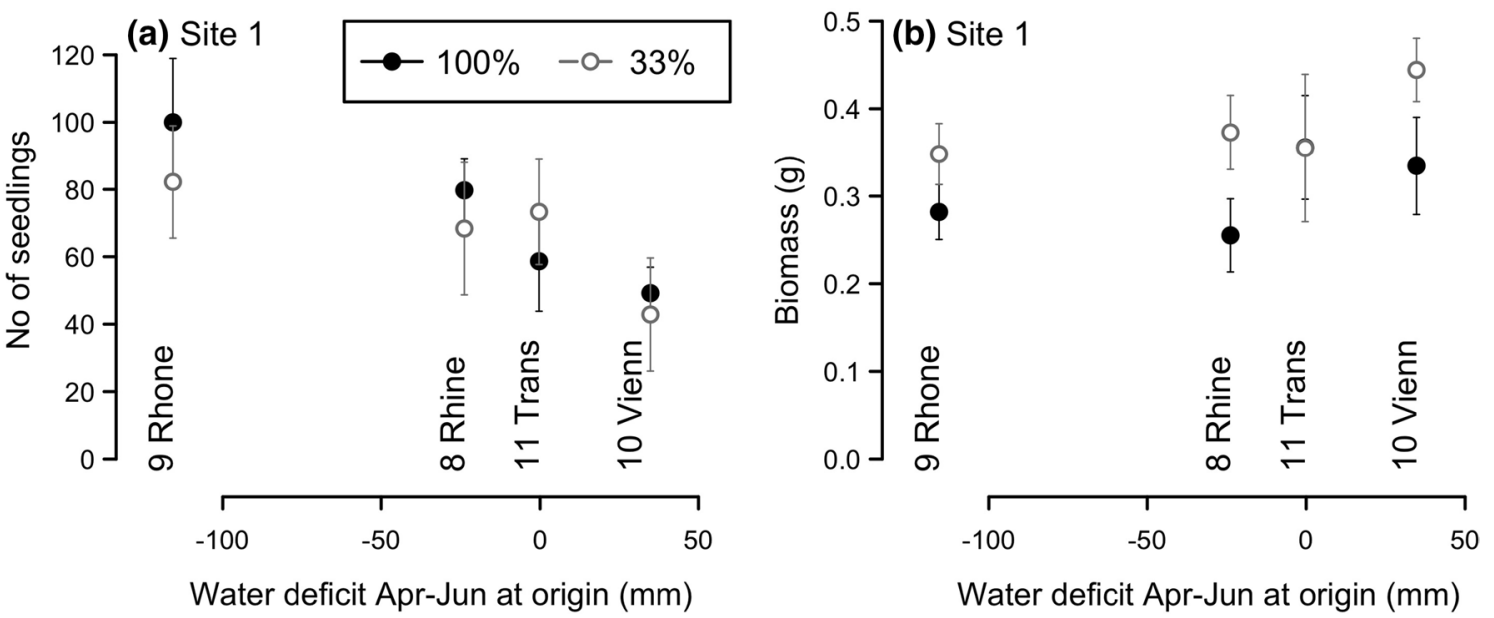

Fig. 4 a Number of Picea abies seedlings at the end of the first growing season in 2013 and $\mathbf{b}$ their average biomass at the end of the second growing season $( \pm \mathrm{SE})$ at study site 1 in relation to average climatic spring water deficit at the seed origin (s. Table 1)

forest systems (Dobrowski et al. 2015). In P. sylvestris, the effect of climatic spring water balance on seedling abundance and size was amplified by soil characteristics with a fivefold difference in seedling biomass between the driest and the wettest year at site 1 (high AWC) and a threefold difference at site 3 (low AWC; Fig. 2). Since precipitation, temperature and nutrient availability were similar at all sites, we attribute these site effects to AWC, the sole characteristic that differentiates them. Low AWC indicates high percolation of precipitation and thus rapid drying out of the soil, whereas high amounts of fine earth at site 1 might facilitate the capillary rise of soil water from the subsoil to the topsoil. The latter might also explain why the throughfall reduction roofs had no effect on soil moisture at site 1. It remains unclear, though, if larger differences in actual precipitation reduction between the two roof types would have resulted in similar soil moisture conditions at the drier sites. The high proportion of rainfall intercepted by the $100 \%$-roofs is unfortunate but was compensated by the high inter-annual variation in natural precipitation, which by chance included an average, a dry and a wet year, corresponding roughly to the mean, the mean negative SD, and the mean positive $\mathrm{SD}$, respectively, of the long-term spring precipitation in the Rhine valley (Online Resource $5)$. Based on this inter-annual variation in precipitation, we conclude that both species are able to regenerate in all but dry years on soils with high AWC. By contrast, successful seedling establishment on low AWC soils is tied to exceptionally wet spring weather. The latter particularly holds for P. abies and mirrors the species' ecological niche, which does not extend to environments as dry as those colonised by P. sylvestris (Ellenberg 1988). Although climate models project a decline of summer precipitation in Central Europe by up to $-40 \%$ by 2100 (CH2011 2011), our results suggest that huge inter-annual variability of weather conditions will continue to be the basis of long-term forest regeneration (Grubb 1977) in large parts of both species' natural distribution ranges, and only a small proportion of conifer forests might become vulnerable to climate change driven regeneration failure. This is corroborated by projections of spring precipitation, which seems to be less likely to change in the future than summer precipitation (Hawkins and Sutton 2011). A comparison of climate data shows that already today the spring water balance is lower in the Central Alpine Rhone, Aosta and Venosta valleys than in the Rhine valley, where our experimental sites were located (Online Resource 5). Even in the event of a $3 \mathrm{~K}$ temperature increase during the spring season, as, e.g., projected for lowland Switzerland by the end of the twenty-first century based on the A2 and A1B climate change scenarios (CH2011 2011), the spring climate of the Rhine valley will, on average, remain moister than today's climate in the Rhone and Aosta valleys, where P. sylvestris and P. abies have both persisted to date. In the Rhone valley, increased mortality of $P$. sylvestris has been observed at low elevations after periods of consecutive dry years (Rigling et al. 2013). Yet, this species is known for its resilience after drought (Eilmann et al. 2010) and it has been suggested that currently observed changes in P. sylvestris stands are the result of an intricate mixture of drought stress, stand age, stand density (Giuggiola et al. 2013), and land-use changes (Gimmi et al. 2010).

\section{Populations from drier climates}

The uniform projections of rising temperatures and declining summer precipitation fostered the idea that drought adapted ecotypes of temperate tree species might be better 
suited to the future climatic conditions in temperate Europe than autochthonous populations (Kapeller et al. 2012; Hanewinkel et al. 2013; Bussotti et al. 2015). Local adaptation to summer drought has been found in all major European tree species (Fagus sylvatica: Sánchez-Gómez et al. 2013; Thiel et al. 2014; Picea abies: Modrzyński and Eriksson 2002; Pinus sylvestris: Richter et al. 2012; Taeger et al. 2013). Nevertheless, ecotypic differences between populations in terms of photosynthetic activity and seedling biomass were small compared to the effects of spring weather and site characteristics, and they were restricted to very dry conditions (site 3 with low AWC $\times 33 \%$ roof; Fig. 3 ). Under these circumstances, the climatic water deficit at the origin during spring rather than during the summer season was related to seedling performance. The suitability of different populations to future climatic conditions will thus depend as much on the seasonal timing as on the intensity of future droughts. Our study suggests that Central Alpine populations of temperate European conifers are likely to be better adapted to the future climatic conditions in Central Europe than Mediterranean populations, because they are adapted to highly variable spring weather and a lower climatic spring water balance (Fig. 1). In the Mediterranean, by contrast, water is generally abundant during winter until late spring, which enables seeds to germinate and establish before the onset of the summer drought (Castro et al. 2004; Castro 2006).

\section{Conclusions}

Regeneration of $P$. sylvestris and $P$. abies in dry Alpine regions such as the Rhine valley is tied to years with favourable spring weather conditions. During such windows of opportunity, the majority of seedlings are able to establish, independent of their origin. Even under changing climatic conditions, autochthonous populations will thus regenerate as successfully as non-native populations from more drought prone regions given that the frequency of years with favourable weather conditions does not decline dramatically. Tree regeneration pulses might become less frequent, because on the one hand rising temperatures will increase the climatic water deficit even if spring precipitation should remain constant (Hawkins and Sutton 2011), and on the other hand tree recruitment also depends on seed availability, which varies tremendously between years (Nussbaumer et al. 2016). The concurrence of mass seed production (masting) and favourable weather conditions might be particularly important after large-scale disturbance events such as windthrow or fire (Moser et al. 2010). Nonetheless, our study supports the perception that landscape heterogeneity is likely to buffer the effects of changing climatic conditions in many ecosystems in some ways and to some extent (Fridley et al. 2011; Scherrer and Körner 2011; Fridley and Wright 2012; García-Palacios et al. 2012; Lenoir et al. 2013; Piper et al. 2013; von Arx et al. 2013; Slavich et al. 2014). It suggests that considerable buffering potential not only exists with respect to soil heterogeneity and topography, but also regarding the timing of regeneration and growth processes, which might (Laube et al. 2014), but not necessarily, be affected by climatic change.

Acknowledgements We are grateful to E. Schnider and A. Walter for their invaluable help in setting up and running the experiment. We also acknowledge the field and laboratory work of C. Bachofen, $\mathrm{H}$. Bachofen, C. Baumann, H. Ding, R. Köchli, K. Kramer, S. Kreuzer, Z. Michalova, J. Müller, T. Reich, S. Steinböck, D. Trummer, and E. Wilson. Seed collection was organised and assisted by S. Berdos, C. Calderón Guerrero, G. Golesch, B. Kinigadner, I. Latchev, A. Tashev und N. Tashev. Climate data were provided by MeteoSwiss, the Swiss Federal Office of Meteorology and Climatology.

Author contribution statement TW and BM conceived and designed the experiment. BM, TW, MM, UW, and LW conducted the fieldwork. BM analysed the data, LW collaborated in soilanalysis. $\mathrm{BM}$ wrote the manuscript with editorial advice from other authors.

\section{Compliance with ethical standards}

Funding The project was funded by the BAFU/WSL initiative "Wald und Klimawandel" and the Amt für Wald und Naturgefahren des Kantons Graubünden. MM is supported by grant IUT21-4 of the Estonian Ministry of Education and Research.

Conflict of interest The authors declare that they have no conflict of interest.

\section{References}

Aitken SN, Yeaman S, Holliday JA, Wang TL, Curtis-McLane S (2008) Adaptation, migration or extirpation: climate change outcomes for tree populations. Evol Appl 1:95-111. doi:10.1111/j.1752-4571.2007.00013.x

Bigler C, Bräker OU, Bugmann H, Dobbertin M, Rigling A (2006) Drought as an inciting mortality factor in Scots pine stands of the Valais, Switzerland. Ecosystems 9:330-343. doi:10.1007/ s10021-005-0126-2

Bussotti F, Pollastrini M, Holland V, Bruggemann W (2015) Functional traits and adaptive capacity of European forests to climate change. Environ Exp Bot 111:91-113. doi:10.1016/j. envexpbot.2014.11.006

Carnicer J, Coll M, Ninyerola M, Pons X, Sánchez G, Peñuelas J (2011) Widespread crown condition decline, food web disruption, and amplified tree mortality with increased climate change-type drought. Proc Natl Acad Sci USA 108:1474-1478. doi:10.1073/pnas.1010070108

Castro J (2006) Short delay in timing of emergence determines establishment success in Pinus sylvestris across microhabitats. Ann Bot 98:1233-1240. doi:10.1093/aob/mcl208

Castro J, Zamora R, Hódar JA, Gómez JM (2004) Seedling establishment of a boreal tree species (Pinus sylvestris) at its southernmost distribution limit: consequences of being 
in a marginal Mediterranean habitat. J Ecol 92:266-277. doi:10.1111/j.0022-0477.2004.00870.x

CH2011 (2011) Swiss climate change scenarios CH2011. C2SM, MeteoSwiss, ETH, NCCR Climate, and OcCC, Zürich

Costa JM, Grant OM, Chaves MM (2013) Thermography to explore plant-environment interactions. J Exp Bot 64:3937-3949. doi:10.1093/jxb/ert029

Dobrowski SZ, Swanson AK, Abatzoglou JT, Holden ZA, Safford HD, Schwartz MK, Gavin DG (2015) Forest structure and species traits mediate projected recruitment declines in western US tree species. Glob Ecol Biogeogr 24:917-927. doi:10.1111/geb.12302

Eilmann B, Buchmann N, Siegwolf R, Saurer M, Cherubini P, Rigling A (2010) Fast response of Scots pine to improved water availability reflected in tree-ring width and delta 13C. Plant Cell Environ 33:1351-1360. doi:10.1111/j.1365-3040.2010.02153.x

Ellenberg H (1988) Vegetation ecology of Central Europe. Cambridge University Press, Cambridge

Fischer AM, Keller DE, Liniger MA, Rajczak J, Schär C, Appenzeller $C$ (2015) Projected changes in precipitation intensity and frequency in Switzerland: a multi-model perspective. Int J Climatol 35:3204-3219. doi:10.1002/joc.4162

Fridley JD, Wright JP (2012) Drivers of secondary succession rates across temperate latitudes of the Eastern USA: climate, soils, and species pools. Oecologia 168:1069-1077. doi:10.1007/ s00442-011-2152-4

Fridley JD, Grime JP, Askew AP, Moser B, Stevens CJ (2011) Soil heterogeneity buffers community response to climate change in species-rich grassland. Global Change Biol 17:2001-2011. doi:10.1111/j.1365-2486.2010.02347.x

García-Palacios P, Maestre FT, Bardgett RD, de Kroon H (2012) Plant responses to soil heterogeneity and global environmental change. J Ecol 100:1303-1314. doi:10.1111/j.1365-2745.2012.02014.x

Gimmi U, Wohlgemuth T, Rigling A, Hoffmann CW, Bürgi M (2010) Land-use and climate change effects in forest compositional trajectories in a dry Central-Alpine valley. Ann Forest Sci 67:701. doi:10.1051/forest/2010026

Giuggiola A, Bugmann H, Zingg A, Dobbertin M, Rigling A (2013) Reduction of stand density increases drought resistance in xeric Scots pine forests. Forest Ecol Manag 310:827-835. doi:10.1016/j.foreco.2013.09.030

Grubb PJ (1977) Maintenance of species-richness in plant communities-importance of regeneration niche. Biol Rev Camb Philos Soc 52:107-145. doi:10.1111/j.1469-185X.1977.tb01347.x

Hanewinkel M, Hummel S, Cullmann DA (2010) Modelling and economic evaluation of forest biome shifts under climate change in Southwest Germany. Forest Ecol Manag 259:710-719. doi:10.1016/j.foreco.2009.08.021

Hanewinkel M, Cullmann DA, Schelhaas M, Nabuurs G, Zimmermann NE (2013) Climate change may cause severe loss in the economic value of European forest land. Nat Clim Change 3:203-207. doi:10.1038/nclimate1687

Hawkins E, Sutton R (2011) The potential to narrow uncertainty in projections of regional precipitation change. Clim Dyn 37:407418. doi:10.1007/s00382-010-0810-6

Hereş AM, Camarero JJ, López BC, Martínez-Vilalta J (2014) Declining hydraulic performances and low carbon investments in tree rings predate Scots pine drought-induced mortality. Trees Struct Funct 28:1737-1750. doi:10.1007/s00468-014-1081-3

Ibànez I, Clark JS, Dietze MC (2009) Estimating colonization potential of migrant tree species. Global Change Biol 15:1173-1188. doi:10.1111/j.1365-2486.2008.01777.x

Kapeller S, Lexer MJ, Geburek T, Hiebl J, Schüler S (2012) Intraspecific variation in climate response of Norway spruce in the eastern Alpine range: selecting appropriate provenances for future climate. Forest Ecol Manag 271:46-57. doi:10.1016/j. foreco.2012.01.039
Laube J, Sparks TH, Estrella N, Hoefler J, Ankerst DP, Menzel A (2014) Chilling outweighs photoperiod in preventing precocious spring development. Global Change Biol 20:170-182. doi:10.1111/gcb.12360

Lenoir J, Graae BJ, Aarrestad PA, Alsos IG, Armbruster WS, Austrheim G, Bergendorff C, Birks HJB, Bråthen KA, Brunet J, Bruun HH, Dahlberg CJ, Decocq G, Diekmann M, Dynesius M, Ejrnaes R, Grytnes JA, Hylander K, Klanderud K, Luoto M, Milbau A, Moora M, Nygaard B, Odland A, Ravolainen VT, Reinhardt S, Sandvik SM, Schei FH, Speed JDM, Tveraabak LU, Vandvik V, Velle LG, Virtanen R, Zobel M, Svenning JC (2013) Local temperatures inferred from plant communities suggest strong spatial buffering of climate warming across Northern Europe. Global Change Biol 19:1470-1481. doi:10.1111/ gcb. 12129

Leuzinger S, Luo YQ, Beier C, Dieleman W, Vicca S, Körner C (2011) Do global change experiments overestimate impacts on terrestrial ecosystems? Trends Ecol Evol 26:236-241. doi:10.1016/j.tree.2011.02.011

Lévesque M, Rigling A, Bugmann H, Weber P, Brang P (2014) Growth response of five co-occurring conifers to drought across a wide climatic gradient in Central Europe. Agric Forest Meteorol 197:1-12. doi:10.1016/j.agrformet.2014.06.001

Lindner M, Fitzgerald JB, Zimmermann NE, Reyer C, Delzon S, van der Maaten E, Schelhaas M-J, Lasch P, Eggers J, van der MaatenTheunissen M, Suckow F, Psomas A, Poulter B, Hanewinkel M (2014) Climate change and European forests: what do we know, what are the uncertainties, and what are the implications for forest management? J Environ Manag 146:69-83. doi:10.1016/j. jenvman.2014.07.030

Lischke H, Zimmermann NE, Bolliger J, Rickebusch S, Löffler TJ (2006) TreeMig: a forest-landscape model for simulating spatiotemporal patterns from stand to landscape scale. Ecol Model 199:409-420. doi:10.1016/j.ecolmodel.2005.11.046

Mátyás C, Ackzell L, Samuel CJA (2003) EUFORGEN Technical guidelines for genetic conservation and use for Scots pine (Pinus sylvestris). International Plant Genetic Resources Institute, Rome

Modrzyński J, Eriksson G (2002) Response of Picea abies populations from elevational transects in the Polish Sudety and Carpathian mountains to simulated drought stress. Forest Ecol Manag 165:105-116. doi:10.1016/S0378-1127(01)00651-X

Moser B, Temperli C, Schneiter G, Wohlgemuth T (2010) Potential shift in tree species composition after interaction of fire and drought in the Central Alps. Eur J Forest Res 129:625-633. doi:10.1007/s10342-010-0363-6

Moser B, Metslaid M, Walthert L, Wasem U, Wohlgemuth T (2015) Verjüngungspotenzial verschiedener Waldföhren- und Fichtenherkünfte bei variabler Trockenheit. Schweiz Z Forstwes 166:399-407. doi:10.3188/szf.2015.0399

Nussbaumer A, Waldner P, Etzold S, Gessler A, Benham S, Thomsen IM, Jørgensen BB, Timmermann V, Verstraeten A, Soen G, Rautio P, Ukonmaanaho L, Skudnik M, Apuhtin V, Braun S, Wauer A (2016) Patterns of mast fruiting of common beech, sessile and common oak, Norway spruce and Scots pine in Central and Northern Europe. Forest Ecol Manag 363:237-251. doi:10.1016/j.foreco.2015.12.033

Piper FI, Fajardo A, Cavieres LA (2013) Simulated warming does not impair seedling survival and growth of Nothofagus pumilio in the southern Andes. Perspect Plant Ecol Evol Syst 15:97-105. doi:10.1016/j.ppees.2013.02.003

R Core Team (2015) R: a language and environment for statistical computing. R Foundation for Statistical Computing, Vienna

Reinert S, Bögelein R, Thomas FM (2012) Use of thermal imaging to determine leaf conductance along a canopy gradient in European beech (Fagus sylvatica). Tree Physiol 32:294-302. doi:10.1093/ treephys/tps017 
Renwick KM, Rocca ME (2015) Temporal context affects the observed rate of climate-driven range shifts in tree species. Global Ecol Biogeogr 24:44-51. doi:10.1111/geb.12240

Richter S, Kipfer T, Wohlgemuth T, Guerrero C, Ghazoul J, Moser B (2012) Phenotypic plasticity facilitates resistance to climate change in a highly variable environment. Oecologia 169:269 279. doi:10.1007/s00442-011-2191-x

Rigling A, Bigler C, Eilmann B, Feldmeyer-Christe E, Gimmi U, Ginzler C, Graf U, Mayer P, Vacchiano G, Weber P, Wohlgemuth T, Zweifel R, Dobbertin M (2013) Driving factors of a vegetation shift from Scots pine to pubescent oak in dry Alpine forests. Global Change Biol 19:229-240. doi:10.1111/gcb.12038

Sánchez-Gómez D, Robson TM, Gascó A, Gil-Pelegrín E, Aranda I (2013) Differences in the leaf functional traits of six beech (Fagus sylvatica L.) populations are reflected in their response to water limitation. Environ Exp Bot 87:110-119. doi:10.1016/j. envexpbot.2012.09.011

Savage M, Brown PM, Feddema J (1996) The role of climate in a pine forest regeneration pulse in the southwestern United States. Ecoscience 3:310-318

Scherrer D, Körner C (2011) Topographically controlled thermal-habitat differentiation buffers alpine plant diversity against climate warming. J Biogeogr 38:406-416. doi:10.1111/j.1365-2699.2010.02407.x

Scherrer D, Bader MKF, Körner C (2011) Drought-sensitivity ranking of deciduous tree species based on thermal imaging of forest canopies. Agric Forest Meteorol 151:1632-1640. doi:10.1016/j. agrformet.2011.06.019

Schleppi P, Bucher-Wallin I, Hagedorn F, Körner C (2012) Increased nitrate availability in the soil of a mixed mature temperate forest subjected to elevated $\mathrm{CO} 2$ concentration (canopy FACE). Global Change Biol 18:757-768. doi:10.1111/j.1365-2486.2011.02559.x

Skrøppa T (2003) EUFORGEN technical guidelines for genetic conservation and use for Norway spruce (Picea abies). International Plant Genetic Resources Institute, Rome
Slavich E, Warton DI, Ashcroft MB, Gollan JR, Ramp D (2014) Topoclimate versus macroclimate: how does climate mapping methodology affect species distribution models and climate change projections? Divers Distrib 20:952-963. doi:10.1111/ddi.12216

Swidrak I, Gruber A, Oberhuber W (2014) Xylem and phloem phenology in co-occurring conifers exposed to drought. Trees Struct Funct 28:1161-1171. doi:10.1007/s00468-014-1026-x

Taeger S, Fussi B, Konnert M, Menzel A (2013) Large-scale genetic structure and drought-induced effects on European Scots pine (Pinus sylvestris L.) seedlings. Eur J Forest Res 132:481-496. doi:10.1007/s10342-013-0689-y

Teepe R, Dilling H, Beese F (2003) Estimating water retention curves of forest soils from soil texture and bulk density. J Plant Nutr Soil Sci 166:111-119. doi:10.1002/jpln.200390001

Thiel D, Kreyling J, Backhaus S, Beierkuhnlein C, Buhk C, Egen K, Huber G, Konnert M, Nagy L, Jentsch A (2014) Different reactions of central and marginal provenances of Fagus sylvatica to experimental drought. Eur J Forest Res 133:247-260. doi:10.1007/s10342-013-0750-x

Thornthwaite CW (1948) An approach toward a rational classification of climate. Geogr Rev 38:55-94

Thuiller W, Lavorel S, Sykes MT, Araujo MB (2006) Using nichebased modelling to assess the impact of climate change on tree functional diversity in Europe. Divers Distrib 12:49-60. doi:10.1111/j.1366-9516.2006.00216.x

von Arx G, Pannatier EG, Thimonier A, Rebetez M (2013) Microclimate in forests with varying leaf area index and soil moisture: potential implications for seedling establishment in a changing climate. J Ecol 101:1201-1213. doi:10.1111/1365-2745.12121

Walthert L, Zimmermann S, Blaser P, Luster J, Lüscher P (2004) Waldböden der Schweiz. Grundlagen und Region Jura, vol 1. Hep Verlag, Bern

Zackrisson O, Nilsson MC, Steijlen I, Hörnberg G (1995) Regeneration pulses and climate-vegetation interactions in nonpyrogenic boreal Scots pine stands. J Ecol 83:469-483. doi:10.2307/2261600 